\title{
sciendo
}

\section{EVALUATION OF OREGANO (ORIGANUM VULGARE) ESSENTIAL OIL SUPPLEMENTATION ON GROWTH PERFORMANCE, DIGESTIVE ENZYMES, INTESTINAL HISTOMORPHOLOGY AND GUT MICROBIOTA OF BLACK SEA SALMON, SALMO LABRAX}

\author{
Osman Tolga Özel ${ }^{1 \bullet}$, Eyüp Çakmak ${ }^{1}$, Selin Ertürk Gürkan², İsa Coskun², Mustafa Türe ${ }^{4}$ \\ ${ }^{1}$ Department of Aquaculture, Central Fisheries Research Institute, Trabzon, Turkey \\ ${ }^{2}$ Department of Biology, Faculty of Art and Science, Çanakkale Onsekiz Mart University, Çanakkale, Turkey \\ ${ }^{3}$ Department of Animal Science, Faculty of Agriculture, Kırşehir Ahi Evran University, Kırşehir, Turkey \\ ${ }^{4}$ Department of Fisheries Health, Central Fisheries Research Institute, Trabzon, Turkey \\ •Corresponding author: osmantolgaozel@gmail.com
}

\begin{abstract}
This study aimed to determine the effect of dietary oregano (Origanum vulgare) essential oil (EO) on the growth performance, digestive enzyme activity, intestinal histomorphology, and intestinal microbiota of the Black Sea salmon juvenile (Salmo labrax). Fish were fed diets different levels of oregano EO such as 50, 100, 200, and $400 \mathrm{mg} \mathrm{kg}^{-1}$. For this purpose, a total of 675 fish were distributed randomly in triplicate into 5 experiment groups in 15 experiment tanks. Fish with average initial weights of $3.52 \pm 0.01 \mathrm{~g}$ were fed by hand at $3 \%$ of live weight for 90 days. At the end of the study, feeding with oregano EO supplementation did not significantly affect the growth performance of fish. Except for pepsin, there were no significant differences in the activity of digestive enzymes among the control and oregano EO groups. Besides, oregano EO at the doses of 50 or $400 \mathrm{mg} \mathrm{kg}^{-1}$ may have the potential to increase the surface area required for digestion by increasing intestinal villi length. Moreover, all doses of oregano EO showed antimicrobial properties by decreasing the count of lactic acid bacteria in the intestine. Supplementation with 100 and $200 \mathrm{mg} \mathrm{kg}^{-1}$ oregano EO in diets decreased the total coliform, Escherichia coli and lactic acid bacteria counts when compared to the control group. The results showed that oregano EO may positively affect digestion and absorption without adverse effects on the growth performance of Black Sea salmon juvenile.
\end{abstract}

Key words: aquaculture, phytobiotic, villi, enzyme, bacteria

Intensive aquaculture production has significantly increased the consumer demand for fish products for many years. Therefore, some research approaches were developed to enhance the growth and productivity of fish farms (Munglue et al., 2019). Immunostimulants, prebiotics, probiotics and phytogenics can be efficiently used as functional dietary supplement to fish feeds (Abo-State et al., 2017). Phytogenic feed additives or phytobiotics are natural bioactive products derived from plants that positively affect the growth and health of animals in animal nutrition (Roofchaee et al., 2011; Ahmadifar et al., 2020). They have several beneficial effects such as antiviral, antimicrobial, antifungal, anti-inflammatory and anti-oxidative activities (Abo-State et al., 2017). Moreover, they can be used for disease control, immune response and resistance of fish, or storage quality improvement and antioxidant properties of the fillet (Giannenas et al., 2012). Among these substances, essential oils can be considered in fish diets because of their positive effects on the growth performance, gut health and wellbeing of the treated fish (Dawood et al., 2021). Besides, they can be used as natural growth promoters in animal diets instead of antibiotics as well as they are used as to promote growth and to enhance immune responses in rabbit, pigs, poultry and ruminants (Amer et al., 2018).

Oregano (Origanum vulgare) is a plant that belongs to the family Labiatae with distribution throughout the Mediterranean area (Zheng et al., 2009). The major components of the oregano essential oil (EO) are carvacrol and thymol (Ahmadifar et al., 2011; Tan et al., 2015; Zheng et al., 2009). Research studies proved that oregano EO has antimicrobial, antifungal, antioxidant (Ahmadifar et al., 2011), antibacterial, anti-inflammatory, anthelminthic, pro-digestive properties and growth promoting effects when being added to animal diets (Ferreira et al., 2016). In addition, it has an effective role in reducing the feeding cost, preventing disease and increasing the growth performance in animals (Ahmad et al., 2009). Studies about usage of oregano EO in the diet of monogastric animals such as poultry, pigs and fish have been daily increased (Heluy et al., 2020). Dietary inclusion of $O$. vulgare or oregano EO successfully improved growth performance in Nile tilapia (Oreochromis niloticus) fingerlings (Mohammadi et al., 2020; Seden et al., 2009), growth performance and muscle growth in catfish (Carneiro et al., 2021), enhanced the hepato-renal functions 
and the activities of catalase and superoxide dismutase in common carp (Cyprinus carpio L.) (Abdel-Latif et al., $2020 \mathrm{a}, \mathrm{b}$ ), enhanced the liver antioxidant system and protected the hepatocytes in rainbow trout (Rafieepour et al., 2019).Fish gut has a provital role in the digestion and absorption of dietary nutrients (Khojasteh, 2012). Small intestine plays an important role in fish productivity as it is the main place of nutrient absorption. When the intestinal villi are long, they can improve the intestinal health, nutrient absorption efficiency and overall fish performance (Abd El-Naby et al., 2019). Lactic acid bacteria (LAB) are a part of the natural intestinal microflora of a healthy fish with noticeable probiotic properties. LAB often produce bacteriocin which inhibits the growth of gram negative fish pathogens (Mohapatra et al., 2012). The digestive potential of fish varies according to age, species, size, food and feeding history, maturity stage and temperature. Knowing the nutritional habits of different fish species related to enzyme activities in the digestive system is important in terms of providing an appropriate diet for each species, as the effectiveness of digestive enzymes is highly reflected in dietary changes (Gioda et al., 2017). The digestion of nutrients in the digestive system of fish is largely dependent on the digestive enzymes present. Therefore, determination of digestive enzyme activity is of potential interest in obtaining and complementing valuable information on the digestive physiology of fish (Hani et al., 2018). Digestive physiology in fish may vary depending on the population of microorganisms operating in the intestines, the activity of digestive enzymes and the morphology of the intestinal villi. Therefore, the addition of natural functional feed additives to fish food is likely to have a positive effect on monogastric animals such as fish.

Black Sea salmon (Salmo labrax) is a subspecies of the brown trout, distributed at the Eastern Black Sea, and an endemic species for Turkey (Tabak et al., 2002). This species has become an important aquaculture species of Turkey in recent years by means of the studies carried out by Central Fisheries Research Institute over the years (Özel et al., 2018). The main aim of this study was to determine the effects of $O$. vulgare EO on digestive physiology of Black Sea salmon.

\section{Material and methods}

\section{Fish material}

Black Sea salmon, Salmo labrax was selected as the primary material of this study due to becoming an essential species for the Turkish aquaculture sector, given increasing trends of the annual productions. All individual fishes were cultured in the Central Fisheries Research Institute, and the fifth filial generation of Black Sea salmon, which was the latest culture line when the study conducted, was used. In this study, a total of 675 Black Sea salmon individuals ( $3.52 \pm 0.01 \mathrm{~g}$ mean weight) for 5 treatments as triplicates $(n=3)$ were used.

\section{Experimental diets}

Oregano (O. vulgare) was selected as the main essential oil source due to its wide accessibility and studies performed on their potential benefits. Oregano EO was supplied from Talya Herbal Products operating in Antalya, Turkey and extracted from cultured $O$. vulgare provided from the Mediterranean region of Turkey. Essential oils are insoluble in aqueous solutions, liquid, and having yellow appearances. Specific gravity was $0.935 \mathrm{~g} / \mathrm{cm}^{3}$, $0.899 \mathrm{~g} / \mathrm{cm}^{3}, 0.922 \mathrm{~g} / \mathrm{cm}^{3}$, refractive index was 1.49071 , $1.47037,1.47037$ for oregano, laurel, and fennel oils in $25^{\circ} \mathrm{C}$, respectively. Physical and chemical specifications of the essential oils conform to the industrial standards. To better understand the chemical mechanisms that lie behind the benefits of these supplements, biochemical compounds of essential oils were determined. The analyses were carried out by Anadolu University with the Agilent GC/MS system (7890B-5977B model) having an HP-Innowax column $(60 \mathrm{~m} \times 0.25 \mathrm{~mm} \times 0.25 \mu \mathrm{m})$. In the analysis, the carrier gas was selected as helium $(0.7 \mathrm{ml} /$ $\mathrm{min}$ ), injection temperature was set as $250^{\circ} \mathrm{C}$, ion source temperature was set as $230^{\circ} \mathrm{C}$, and $70 \mathrm{eV}$ electron was used for ionization. Ultimately, obtained results were evaluated with Wiley 9-Nist 11 Mass Spectral Database in Anadolu University. The biochemical composition of oregano EO was shown in Table 1.

Table 1. Chemical compounds of oregano EO

\begin{tabular}{lc}
\hline \multicolumn{1}{c|}{ Compound } & $\%$ \\
\hline Carvacrol & 68.3 \\
$\rho$-Cymene & 9.2 \\
Thymol & 5.2 \\
$\gamma$-Terpinene & 4.3 \\
$\beta$-Caryophyllene & 2.1 \\
Linalool & 0.5 \\
Myrcene & 1.4 \\
Caryophyllene oxide & 1.0 \\
Borneol & 0.9 \\
Terpinen-4-ol & 0.8 \\
$\alpha$-Terpinene & 0.8 \\
$\alpha$-Pinene & 0.6 \\
\hline
\end{tabular}

The most abundant chemical compounds of essential oils were listed according to amounts that were found higher than $0.5 \%$.

In studies with $O$. vulgare, levels ranging from $0.5 \mathrm{~g} / \mathrm{kg}$ to $20 \mathrm{~g} / \mathrm{kg}$ were generally used in aquafeeds (Abdel-Latif et al., 2020 b; Ferreira et al., 2016; Heluy et al., 2020; Rafieepour et al., 2019; Zhang et al., 2019). Our study contained lower oregano EO which were at doses of 50,100, 200 and $400 \mathrm{mg} \mathrm{kg}^{-1}$ and defined as oregano 50 , oregano 100 , oregano 200 , oregano 400 , encoded as $\mathrm{O} 50, \mathrm{O} 100, \mathrm{O} 200, \mathrm{O} 400$, respectively. The above amounts were added to fish oil and then penetrated with vacuum coating to feeds prepared. Five experimental diets were formulated, including control. The control 
diet was did not contain any oregano EO. Fish meal was a mixture of European sprat (Sprattus sprattus) and Atlantic herring (Clupea harengus) meals containing $65.37 \%$ of crude protein and $10.7 \%$ of crude lipid, whereas fish oil was European anchovy (Engraulis encrasicolus) oil which is amongst the most used feed ingredient sources. Ingredients and nutrient compositions of diet were shown in Table 2.

\section{Feed analysis}

Crude protein was determined by the Kjeldahl procedure ( $\mathrm{N} x$ 6.25), crude lipid by the Soxhlet method using diethyl ether, crude fiber by boiling with acids and alkalis, moisture by drying samples to constant weight at $105^{\circ} \mathrm{C}$, and crude ash by incineration at $550^{\circ} \mathrm{C}$ for 12 h (AOAC, 1990). NFE were determined by calculation.

Table 2. Formulation and proximate composition of the base diet (\%)

\begin{tabular}{|c|c|}
\hline Ingredients & $\%$ \\
\hline Fish meal & 31 \\
\hline Soybean meal & 20 \\
\hline Wheat gluten & 6 \\
\hline Pea protein & 12 \\
\hline Sunflower seed meal & 7 \\
\hline Wheat flour & 12.5 \\
\hline Fish oil & 11 \\
\hline Vitamin $\operatorname{mix}^{1}$ & 0.22 \\
\hline Mineral $\operatorname{mix}^{2}$ & 0.16 \\
\hline Vit. C & 0.12 \\
\hline \multicolumn{2}{|l|}{ Proximate composition } \\
\hline crude protein & 46.20 \\
\hline crude lipid & 14.97 \\
\hline crude ash & 9.38 \\
\hline crude fiber & 5.34 \\
\hline moisture & 6.14 \\
\hline NFE & 17.97 \\
\hline $\mathrm{ME}(\mathrm{Kcal} / \mathrm{kg})$ & 3593.45 \\
\hline
\end{tabular}

${ }^{1}$ Supplied the following: inositol $300 \mathrm{mg}$, biotin (Vit. $\mathrm{B}_{7}$ ) $200 \mathrm{mg}$, tocopherol (Vit. E) $200 \mathrm{mg}$, calcium pantothenate (Vit. $\left.\mathrm{B}_{5}\right) 50 \mathrm{mg}$, riboflavin (Vit. B $) 30 \mathrm{mg}$, pyridoxine (Vit. B $) 20 \mathrm{mg}$, thiamine (Vit. B , $_{1} 20 \mathrm{mg}$, menadione (Vit. $\left.\mathrm{K}_{3}\right) 12 \mathrm{mg}$, niacin (Vit. $\mathrm{B}_{3}$ ) $6 \mathrm{mg}$, retinol (Vit. A) $0.6 \mathrm{mg}$, folic acid (Vit. $\mathrm{B}_{9}$ ) $0.5 \mathrm{mg}$, cholecalciferol (Vit. $\mathrm{D}_{3}$ ) $0.05 \mathrm{mg}$, cobalamin (Vit. $\mathrm{B}_{12}$ ) $0.05 \mathrm{mg}$.

${ }^{2}$ Supplied the following: ferric sulfate heptahydrate $\left(\mathrm{FeSO}_{4} \cdot 7 \mathrm{H}_{2} \mathrm{O}\right)$ $50 \mathrm{mg}$, manganese (II) oxide ( $\mathrm{MnO}) 50 \mathrm{mg}$, zinc oxide ( $\mathrm{ZnO}) 50 \mathrm{mg}$, copper sulfate pentahydrate $\left(\mathrm{CuO}_{4} \mathrm{~S} \cdot 5 \mathrm{H}_{2} \mathrm{O}\right) 10 \mathrm{mg}$, calcium iodate $\left(\mathrm{Ca}_{2} \mathrm{IO}_{6}\right)$ $0.8 \mathrm{mg}$, cobalt carbonate hexahydrate $\left(\mathrm{CoCO}_{3} \cdot 6 \mathrm{H}_{2} \mathrm{O}\right) 0.15 \mathrm{mg}$, sodium selenite $\left(\mathrm{Na}_{2} \mathrm{SeO}_{3}\right) 0.15 \mathrm{mg}$.

\section{Maintenance and feeding procedures}

The study was carried out in a freshwater recirculating aquaculture system (RAS) at the Central Fisheries Research Institute in Trabzon, Turkey. Fish were placed randomly in $50 \mathrm{~L}(39 \times 39 \mathrm{~cm}$ square, with depths of $33 \mathrm{~cm}$ ) experiment tanks, and each tank housed 45 fish. Up to apparent satiation, fish were fed by hand four times daily at 08:30 am, 11:00 am, 1:30 pm and 4:00 pm. The experiment was conducted for 90 days. Water tem- perature $\left(15.10 \pm 0.98^{\circ} \mathrm{C}\right)$, oxygen $(8.78 \pm 0.21 \mathrm{mg} / \mathrm{l}), \mathrm{pH}$ $(7.43 \pm 0.18)$ and mortality were recorded daily. Ammonia $(0.05 \pm 0.05 \mathrm{mg} / \mathrm{l})$ was measured weekly. Experiments were carried out in square tanks with 22 times water changing daily.

At the end of the experiments, fish individuals were sampled for further analysis. The fish rearing and sampling were carried out according to both the European Union Directive (2010/63/EU) (European Commission, 2010) and ARRIVE ethical guidelines (Kilkenny et al., 2010). Besides, all studies were performed with the approval of the Ethical Committee of Animal Experiments of Central Fisheries Research Institute (coded as ETIK2017/1).

\section{Determination of growth characteristics}

At the end of the experiment, followed by $24 \mathrm{~h}$ of starvation, fish were slightly anesthetized with $50 \mathrm{mg} \mathrm{L}^{-1}$ benzocaine (Oswald, 1978) and weighed individually. The performance characteristics such as weight gain, specific growth rate, feed conversion ratio and survival rate were calculated with equations shown below. Also, fish were weighed every 15 days to determine the amount of feed intake.

$$
\begin{gathered}
\mathrm{WG} g=[(\text { Final weight }- \text { Initial weight })] \\
\text { FCR }=(\text { Feed intake } \div \text { Weight gain })
\end{gathered}
$$

\section{Sample collection}

Six fish were sampled from each experimental trial group including control group for digestive enzyme, histomorphology and microbiota analyses after determination of fish growth performance.

For determination of the digestive enzyme activities including pepsin, trypsin, amylase and lipase, the digestive tract (midgut) samples were taken after 45 minutes of feeding on the sampling day. Tissue samples were kept at $-80^{\circ} \mathrm{C}$ for the analyses. They were sent to Çanakkale Onsekiz Mart University, Faculty of Arts and Science, Biology Department, Water Ecology Laboratory in the cold chain. For intestinal histomorphology, tissue samples were cut as $1.0 \mathrm{~cm}$ pieces and placed into $10 \%$ formalin for further processing. After that, tissue samples were carried to Kursehir Ahi Evran University, Faculty of Agriculture, Zootechnical Department for the tissue processing. Intestinal tissues were sampled from the initial beginning part of the middle intestine, which is the final point of section attached to the intestine of pyloric caeca. The intestinal tracts of fish sampled for microbiota examination were aseptically moved in the Fish Health laboratory of Central Fisheries Research Institute.

\section{Determination of digestive enzyme activity}

The tissue samples were weighed and homogenized in a 1:5 ratio with homogenization buffer $(0.05$ phosphate buffer $\mathrm{pH}$ 7.4). The specific activity of each enzyme evaluated in the study was measured spectrophotometrically; values obtained should be proportioned to the protein 
value in homogenate to be interpreted in terms of $\mathrm{mU} /$ mg protein ${ }^{-1}$. Therefore, the amount of protein in the homogenate was also determined. Bradford (1976) method was used to calculate the amount of protein. The protein value obtained was measured for each enzyme and the specific activity was calculated as $\mathrm{mU} / \mathrm{mg}$ protein ${ }^{-1}$. For the measurement of trypsin enzyme activity, the analysis method of Tseng et al. (1982) was used, and method of Na-benzoyl-DL-arginine-p-nitroanilide (BAPNA) was used as substrate. Enzyme activities were measured in a spectrophotometer at $253 \mathrm{~nm}$ wavelength for 5 minutes. Measurement of pepsin enzyme activity was performed using a revised version of the analysis method of Worthington (1982) by Infante and Cahu (1994). Besides, bovine hemoglobin was used as a substrate. Samples were measured at a wavelength of $280 \mathrm{~nm}$ for 5 minutes. In order to monitor the $\alpha$-amylase enzyme activity, the analysis method used in the study was based on Bieth and Metais (1968) and soluble starch was used as a substrate. Samples were measured at $540 \mathrm{~nm}$ wavelength for 5 minutes. In order to measure lipase enzyme activity, $\alpha$-naphthyl caprylate was used as substrate in the study conducted by Versaw et al. (1989). Spectrophotometric measurement was done at $490 \mathrm{~nm}$ wavelength for 10 minutes.

\section{Evaluation of intestinal histomorphology}

Tissues were sent into tissue cassettes for dehydration process and were embedded in paraffin blocks, and subsequently cut into $5-\mu$ thickness and placed on a slide. A tissue sample of each intestine was prepared and stained with hematoxylin and eosin solution by using the standard paraffin-embedding procedure. After the embedding process, muscularis thickness, villi length and villi width were photographed with ZEISS Primostar HD Light microscope and evaluated by using an image processing and analysis system. Ten measurements were made from each fish for histomorphologic analyses.

\section{Evaluation of intestinal microbiota}

One gram of digestive content was homogenized with $9 \mathrm{ml}$ of $0.1 \%$ peptone-water containing $0.9 \% \mathrm{NaCl}$ using the stomacher apparatus (BagMixer CC, Interscience). Five-fold serial dilutions of content were prepared and streaked on de Man, Rogosa and Sharpe (MRS, Merck) for the count of the lactic acid bacteria (LAB). LAB was allowed to incubate at $30^{\circ} \mathrm{C}$ for $48 \mathrm{~h}$ in anaerobic jars (Merck) (Harrigan and McCance, 2017). The dilution $(100 \mu \mathrm{l})$ was also streaked on Coliform Agar (CES, Merck) and incubated for $24 \mathrm{~h}$ at $35^{\circ} \mathrm{C}$ for the count of the total aerobic mesophilic bacteria (TAMB) and EScherichia coli (Ture et al., 2018). At the end of incubation, the total number of LAB, E. coli and TAMB were calculated by counting the colony-forming units.

\section{Statistical analyses}

Results are expressed as means with standard errors (SE). Data were statistically analyzed by one-way analysis of variance (ANOVA) procedure of SPSS 21.0. Differences between means were compared using Duncan's multiple range test. The intestinal microbiota data were $\log 10$ transformed, then analyzed. Probability levels of $\mathrm{P}<0.05$ were chosen for statistical significance.

\section{Results}

\section{Growth performance}

All the experiment feeds including control were willingly consumed by fish. The final weight (FW), weight gain (WG), specific growth rate (SGR), feed conversion rate (FCR), feed intake (FI) and survival rate (SR) were not influenced linearly and quadratically by dietary inclusion of $O$. vulgare $(\mathrm{P}>0.05)$. As the doses of oregano oil in the diet increased, growth parameters including $\mathrm{FW}$, WG, FCR, SGR and FI decreased, but not statistically significantly (Table 3 ).

Table 3. Growth parameters of Black Sea salmon fed with oregano EO supplemented diets

\begin{tabular}{|c|c|c|c|c|c|c|c|c|}
\hline & \multicolumn{5}{|c|}{ Doses of Origanum vulgare EO (mg/kg) } & \multirow{2}{*}{$P$ values } & \multicolumn{2}{|c|}{ Polynomial model } \\
\hline & 0 & 50 & 100 & 200 & 400 & & linear & quadratic \\
\hline IW & $3.52 \pm 0.01$ & $3.52 \pm 0.01$ & $3.52 \pm 0.01$ & $3.52 \pm 0.00$ & $3.52 \pm 0.00$ & 0.965 & 1.000 & 0.488 \\
\hline FW & $29.83 \pm 1.10$ & $32.05 \pm 0.63$ & $30.67 \pm 0.57$ & $30.01 \pm 0.39$ & $29.04 \pm 0.64$ & 0.107 & 0.215 & 0.089 \\
\hline FI & $23.30 \pm 0.72$ & $24.57 \pm 0.05$ & $23.98 \pm 0.24$ & $23.30 \pm 0.11$ & $23.04 \pm 0.59$ & 0.154 & 0.256 & 0.838 \\
\hline WG & $26.31 \pm 1.11$ & $28.53 \pm 0.63$ & $27.15 \pm 0.57$ & $26.49 \pm 0.39$ & $25.51 \pm 0.64$ & 0.106 & 0.215 & 0.088 \\
\hline FCR & $1.07 \pm 0.06$ & $0.95 \pm 0.02$ & $0.99 \pm 0.05$ & $1.02 \pm 0.03$ & $1.09 \pm 0.05$ & 0.155 & 0.602 & 0.870 \\
\hline SGR & $2.30 \pm 0.04$ & $2.37 \pm 0.02$ & $2.33 \pm 0.02$ & $2.30 \pm 0.01$ & $2.27 \pm 0.02$ & 0.104 & 0.233 & 0.084 \\
\hline SR & $91.85 \pm 2.67$ & $92.59 \pm 3.23$ & $94.82 \pm 2.96$ & $88.89 \pm 4.63$ & $92.59 \pm 0.74$ & 0.756 & 0.825 & 0.852 \\
\hline
\end{tabular}

No difference between means $(\mathrm{P}>0.05)$, values are given as means with standard errors. IW: Initial weight, FW (g): Final weight, FI (g): Feed intake, FCR: Feed conversion rate, WG (g): Weight gain, SGR (\%): Specific growth rate, SR (\%): Survival rate. Control diet contains zero dose of EO. 
Table 4. The activity of digestion enzymes of Black Sea salmon fed with oregano EO supplemented diets, $\mathrm{U} \mathrm{mg}^{-1}$

\begin{tabular}{|c|c|c|c|c|c|c|c|c|}
\hline & \multicolumn{5}{|c|}{ Doses of Origanum vulgare EO (mg/kg) } & \multirow{2}{*}{$P$ values } & \multicolumn{2}{|c|}{ Polynomial model } \\
\hline & 0 & 50 & 100 & 200 & 400 & & linear & quadratic \\
\hline Pepsin & $69.95 \pm 7.29 \mathrm{ab}$ & $39.44 \pm 0.49 \mathrm{c}$ & $92.19 \pm 15.65 \mathrm{a}$ & $32.95 \pm 1.62 \mathrm{c}$ & $55.05 \pm 0.41 \mathrm{bc}$ & 0.020 & 0.170 & 0.820 \\
\hline Trypsin & $34.52 \pm 5.93$ & $31.36 \pm 4.19$ & $35.21 \pm 3.41$ & $28.80 \pm 1.84$ & $35.90 \pm 2.18$ & 0.660 & 0.986 & 0.489 \\
\hline$\alpha$-Amylase & $1.46 \pm 0.45$ & $2.50 \pm 1.71$ & $4.53 \pm 0.49$ & $2.99 \pm 0.85$ & $2.57 \pm 0.33$ & 0.280 & 0.280 & 0.088 \\
\hline Lipase & $0.02 \pm 0.00$ & $0.05 \pm 0.02$ & $0.04 \pm 0.01$ & $0.01 \pm 0.01$ & $0.03 \pm 0.01$ & 0.427 & 0.491 & 0.485 \\
\hline
\end{tabular}

Means with different letters in a row are significantly different at $\mathrm{P}<0.05$, values are given as means with standard errors. Control diet contains zero dose of EO.

Table 5. Intestinal morphology of Black Sea salmon fed with oregano EO supplemented diets, $\mu \mathrm{m}$

\begin{tabular}{|c|c|c|c|c|c|c|c|c|}
\hline & \multicolumn{5}{|c|}{ Doses of Origanum vulgare EO (mg/kg) } & \multirow{2}{*}{$P$ values } & \multicolumn{2}{|c|}{ Polynomial model } \\
\hline & 0 & 50 & 100 & 200 & 400 & & linear & quadratic \\
\hline VL & $223.80 \pm 5.35 b$ & $274.07 \pm 10.96 \mathrm{a}$ & $238.89 \pm 9.05 \mathrm{~b}$ & $232.28 \pm 9.32 \mathrm{~b}$ & $252.05 \pm 12.51 \mathrm{ab}$ & 0.005 & 0.634 & 0.376 \\
\hline VW & $65.15 \pm 2.88 \mathrm{~b}$ & $65.95 \pm 4.70 \mathrm{~b}$ & $70.96 \pm 4.55 \mathrm{~b}$ & $61.78 \pm 4.38 \mathrm{~b}$ & $88.77 \pm 5.67 \mathrm{a}$ & 0.001 & 0.004 & 0.027 \\
\hline Muscularis & $44.53 \pm 1.82 \mathrm{c}$ & $46.88 \pm 2.32 \mathrm{bc}$ & $54.51 \pm 2.30 \mathrm{~b}$ & $62.38 \pm 4.20 \mathrm{a}$ & $40.48 \pm 2.25 \mathrm{c}$ & 0.000 & 0.390 & 0.000 \\
\hline VL/VW & $3.58 \pm 0.25$ & $4.74 \pm 0.75$ & $3.59 \pm 0.33$ & $4.02 \pm .0 .31$ & $3.02 \pm 0.26$ & 0.072 & 0.178 & 0.088 \\
\hline
\end{tabular}

Means with different letters in a row are significantly different at $\mathrm{P}<0.05$, values are given as means with standard errors. VL: Villi length, VW: Villi width. Control diet contains zero dose of EO.

Table 6. Intestinal microbiota of Black Sea salmon fed with oregano EO supplemented diets, CFU, log/g

\begin{tabular}{|c|c|c|c|c|c|c|c|c|}
\hline & \multicolumn{5}{|c|}{ Doses of Origanum vulgare EO (mg/kg) } & \multirow{2}{*}{$P$ values } & \multicolumn{2}{|c|}{ Polynomial model } \\
\hline & 0 & 50 & 100 & 200 & 400 & & linear & quadratic \\
\hline E. coli & $5.46 \pm 0.15 b$ & $5.53 \pm 0.17 \mathrm{~b}$ & $3.31 \pm 0.15 \mathrm{c}$ & $3.24 \pm 0.21 \mathrm{c}$ & $6.68 \pm 0.51 \mathrm{a}$ & 0.000 & 0.856 & 0.000 \\
\hline Coliform & $12.47 \pm 0.14 \mathrm{a}$ & $12.42 \pm 0.12 \mathrm{a}$ & $7.51 \pm 0.32 \mathrm{c}$ & $7.84 \pm 0.49 \mathrm{c}$ & $9.81 \pm 0.42 \mathrm{~b}$ & 0.000 & 0.000 & 0.000 \\
\hline Lactic acid & $11.05 \pm 0.04 \mathrm{a}$ & $7.05 \pm 0.20 \mathrm{c}$ & $8.84 \pm 0.13 b$ & $7.25 \pm 0.25 \mathrm{c}$ & $8.61 \pm 0.08 \mathrm{~b}$ & 0.000 & 0.000 & 0.000 \\
\hline
\end{tabular}

Means with different letters in a row are significantly different at $\mathrm{P}<0.05$, values are given as means with standard errors. Control diet contains zero dose of EO.

\section{Enzyme activity}

At the end of the experiment, trypsin, amylase and lipase activities were shown to be similar among the 5 experiment groups, but not in pepsin (Table 4). On the other hand, feeding with oregano EO at the doses of 50 and $200 \mathrm{mg} \mathrm{kg}^{-1}$ caused the decrease of pepsin enzyme activity. Digestion enzyme activities in fish were similar among trial groups, except pepsin activity, which was higher in fish fed diet with $100 \mathrm{mg} \mathrm{kg}^{-1}$ oregano EO. In terms of digestive enzyme activities, a significant relationship was not determined both linearly and quadratically.

\section{Histological examination}

The results were summarized in Table 5 and shown in Figure 1. The villi length (VL), villi width (VW), length to width ratio (VL/VW) and muscularis thick- ness were significantly affected by dietary treatments $(\mathrm{P}<0.05)$. VL and VL/VW were not affected linearly and quadratically by dietary inclusion of $O$. vulgare. However, VW had a significant relationship both linearly and quadratically. Muscularis layer was influenced quadratically by dietary inclusion of $O$. vulgare, but not linearly. The highest villi length was observed in fish fed with oregano EO at the doses of $50 \mathrm{mg} \mathrm{kg}^{-1}$ and followed by those fed with oregano EO at the doses of $400 \mathrm{mg} \mathrm{kg}^{-1}$. Feeding with oregano EO at the doses of $400 \mathrm{mg} \mathrm{kg}^{-1}$ improved intestinal villi width. Supplementation with 50 and $100 \mathrm{mg}$ oregano EO kg-1 diet and control diet were similar in terms of intestinal villi width. Muscularis thickness was highest in fish fed with oregano EO at the doses of $200 \mathrm{mg} \mathrm{kg}^{-1}$ and followed by those fed with oregano EO at the doses of $100 \mathrm{mg} \mathrm{kg}^{-1}$. 

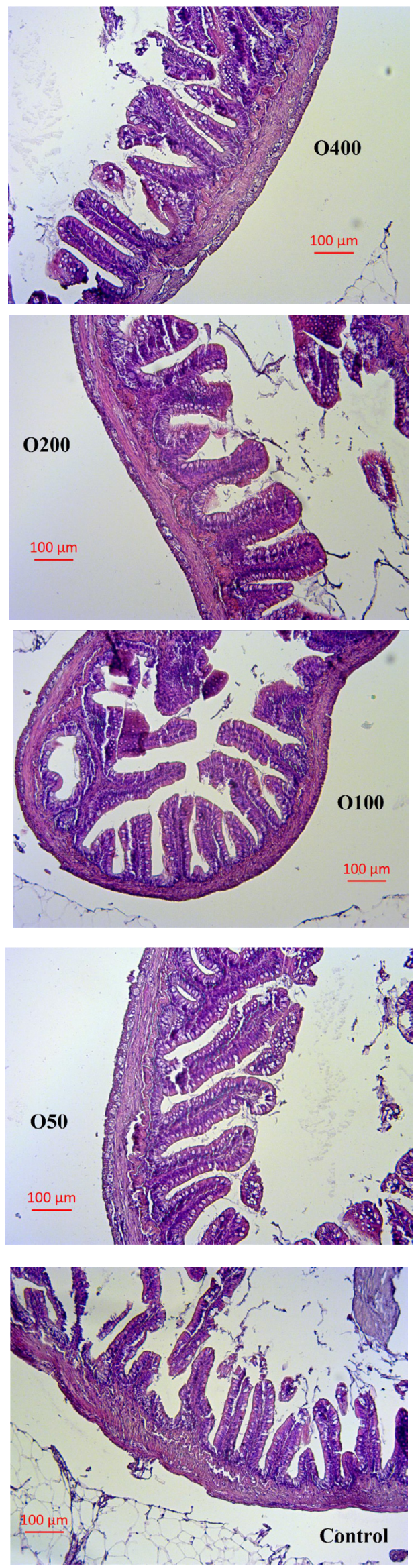

Figure 1. O represent oregano, whereas 50, 100, 200, and 400 represents different doses of essential oils $\left(\mathrm{mg} \mathrm{kg}^{-1}\right)$. Intestinal histology of Black Sea salmon fed with oregano EO supplemented diets (4x, H\&E). Control diet contains zero dose of EO 


\section{Microbiota detection}

The results obtained were shown in Table 6. The intestinal microbiota in fish was significantly affected by dietary oregano EO treatments $(\mathrm{P}<0.05)$. E. coli count was influenced quadratically by dietary inclusion of O. vulgare, but not linearly. However, coliform and lactic acid bacteria had a significant relationship both linearly and quadratically. Fish fed with dietary doses of oregano EO had antimicrobial properties that decreased the number of lactic acid bacteria in fish intestine. Similarly, O100, O200 and O400 had a similar effect on coliform, and $\mathrm{O} 100$ and $\mathrm{O} 200$ on E. coli. O100 and O200 were the only two diets that simultaneously reduced the number of coliforms, E. coli and lactic acid bacteria.

\section{Discussion}

Phytogenics and phytobiotics derived from aromatic plants and their essential oils have been used to improve the growth performance and immune responses of fish (Abdel-Latif et al., 2020 a, b; Khafaga et al., 2020). When compared to synthetic drugs, the use of herbal products in diets as natural feed additives can improve growth performance and feed utilization efficiency without any side effect (Munglue, 2016). Similarly, the addition of dietary oregano EO can increase the growth rate by stimulating appetite in fish (Zheng et al., 2009). Amer et al. (2018) found that while dietary supplementation of thymol $(2 \mathrm{ml}$ $\mathrm{kg}^{-1}$ ) did not increase the growth performance of the Nile tilapia fingerlings, dietary supplementation of thymol $(1 \mathrm{ml} \mathrm{kg}-1)$ increased the growth performance. Dinardo et al. (2021) demonstrated that specific growth rate and final weight of European Sea bass were decreased with O. vulgare EO (200 ppm), but increased with $O$. vulgare EO at a level of $100 \mathrm{ppm}$. Similarly, Carneiro et al. (2021) found that dietary inclusion of oregano EO (2.10 $2.56 \mathrm{~g} \mathrm{~kg}^{-1}$ ) increased growth performance of catfish (Lophiosilurus alexandri). Our study demonstrated that feeding Black Sea salmon with added oregano EO did not have any effect on the growth parameters (FW, WG, SGR, FCR) in fish. In a previous study, Ahmadifar et al. (2011) found that dietary addition of thymol-carvacrol powder at the levels of 2 and $3 \mathrm{~g} \mathrm{~kg}^{-1}$ had a positive effect on the growth performance of rainbow trout juveniles. Furthermore, Ahmad et al. (2009) indicated that dietary O. vulgare extract increased growth performance and feed efficiency in Nile tilapia fingerlings. However, our results with oregano EO are consistent with the results of Heluy et al. (2020) who claimed that dietary supplementation of oregano EO inclusion $(0.75,1.5,2.25$ and $3 \mathrm{~g} \mathrm{~kg}^{-1}$ ) did not increase the growth performance of the Nile tilapia fingerlings. Also, Cararo et al. (2017) found that dietary supplementation with $O$. vulgare EO did not have an increasing effect on the growth performance of silver catfish juveniles, Rhamdia sp. Though, Zheng et al. (2009) found that dietary carvacrol extract at levels of $0.05 \%$ increased weight gain and feed conversion ratio of channel fish, Ictalurus punctatus, but not dietary thymol extract.

Analysis of digestive enzymes provides information on the nutritional physiology of fish, and their ability to utilize different nutritional fractions of the feed (Gioda et al., 2017). Fish improve feed efficiency by digesting the nutrients in the feed with the help of digestive enzymes (Shabana et al., 2019). In this way, the growth performance may be enhanced by stimulation of these enzyme secretions (Amhamed et al., 2018). Fish generally produce different digestive enzymes classified as proteolytic, carbohydrate, lipolytic, and phosphatase (Hani et al., 2017). Thymol and carvacrol derived from oregano EO may enhance the secretion of digestive enzymes (AbdelLatif et al., 2020 a). The addition of oregano EO in the diet stimulates digestive function by increasing the protease, lipase and amylase enzyme activities in koi carp, Cyprinus carpio (Zhang et al., 2019). Similarly, supplementation of Citrus sinensis peel extract at levels of 2, 6, or $10 \mathrm{~g} \mathrm{~kg}^{-1}$ increased the lipase and amylase activities in the Catla catla (Shabana et al., 2019). In our study, feeding with oregano EO had no effect on the trypsin, amylase and lipase enzyme activities. But, pepsin activity in fish fed $100 \mathrm{mg}$ oregano $\mathrm{EO} \mathrm{kg}{ }^{-1}$ was higher than in fish in other groups. Our results are in accordance with those reported by Mohammadi et al. (2020) who found that amylase and lipase activities of Nile tilapia fed with O. vulgare $\mathrm{EO}$ at a level of $0.2 \%$ were similar to control group. In our study, additionally, the effect of oregano EO on lipase and amylase enzyme activities is in accordance with those reported by Magouz et al. (2021) who studied the effects of menthol essential oil on Nile tilapia. Differences between the results obtained from different essential oils may vary depending on the active components, doses of essential oil, and also fish species. Hani et al. (2017) stated that the activity of digestive enzymes varies within species.

Intestinal villi have a crucial role in digestion and absorption of nutrients, and absorptive surface area of the digestive tract is enhanced when intestinal villi length is increased (Munglue et al., 2019). This structure may also be changed depending on the sections of the intestine. Ran et al. (2016) found that there was a difference in the villi length in the hindgut section of the intestine of juvenile hybrid tilapia fed essential oil containing equal levels of thymol and carvacrol, but not in the midgut section. Similarly, Heidarieh et al. (2013) found that in the 6th week of trial, dietary Aloe vera at different levels affected fold length in the pyloric caeca of rainbow trout (Oncorhynchus mykiss), but not in the intestine. Oregano EO increases the height and width of intestinal folds due to its antimicrobial activity and also can improve the digestive and absorptive processes by increasing the surface area of the pleats (Ferreira et al., 2016). In a previous study, Ferreira et al. (2016) found that feeding juvenile yellowtail tetra, Astyanax altiparanae with feed added oregano oil during 90 days had a positive linear effect on their intestinal morphology. In another study Carneiro et 
al. (2021) found that intestinal histomorphometry was not affected by oregano EO. Our study showed that different doses $\left(50,100,200\right.$ and $\left.400 \mathrm{mg} \mathrm{kg}^{-1}\right)$ of oregano EO had positive effects or no effect on the intestinal histomorphology of Black Sea trout. According to Abdel-Latif et al. (2020 a), villus height and width in mid-intestine was increased in common carp (C. carpio) fingerlings fed with dietary oregano $\mathrm{EO}\left(5,10,15\right.$ or $\left.20 \mathrm{~g} \mathrm{~kg}^{-1}\right)$, and this enhanced the growth performance in fish. In an additional study, Abd El-Naby et al. (2019) indicated that feeding Nile tilapia fingerlings with dietary thymol significantly enhanced the intestinal villi length in fish. In our study, similarly, intestinal villi length of fish fed with dietary $50 \mathrm{mg}$ oregano EO kg-1 was increased compared to the control group. Similarly, the feed with $400 \mathrm{mg}$ $\mathrm{kg}^{-1}$ oregano EO enhanced intestinal villi width in fish. However, Heidarieh et al. (2013) reported that feeding rainbow trout with feed added Aloe vera at $0.1-10 \mathrm{~g} \mathrm{~kg}^{-1}$ had no effect on intestinal villi length and villi width of fish in the 6th week of trial, but not first and fourth weeks. Our results with oregano EO (100, 200 and $\left.400 \mathrm{mg} \mathrm{kg}^{-1}\right)$ agree with the results of Valladao et al. (2019) who found that feeding dietary thyme (Thymus vulgaris) essential oil (TVEO) had no significant effect on the intestinal villi length of Nile tilapia. Also, our results with oregano EO at $50 \mathrm{mg} \mathrm{kg}^{-1}$ are consistent with the results of Heluy et al. (2020) who indicated that dietary oregano EO at doses of $0.75,1.5,2.25$ and $3 \mathrm{~g} \mathrm{~kg}^{-1}$ improved intestinal villi length of the Nile tilapia fingerling. As mentioned above, these results may change depending on factors such as fish species, essential oils and their composition and levels, and trial period.

In the finfish, effective performance of the digestive tract and intestinal microbiota play a vital role in host health, and in the absence of intestinal microbiota, normal immune development, and function is impaired (Ringø and Gatesoupe, 2018). Lamiaceae plant can improve digestive processes by synergistic interactions with beneficial gut microbiota. In this context, numerous studies suggested oregano EO can improve the digestibility of food in many animal species, including fish (Espirito Santo et al., 2018). The finding of our study showed that feeding Black Sea salmon with dietary oregano EO had an important effect on intestinal microbiota including E. coli, coliform and lactic acid bacteria. TVEO has the potential to be used as a protective agent in fish (Navarrete et al., 2010). Similarly, thymol, carvacrol, (+)-carvone and trans-cinnamaldehyde essential oils have inhibitory properties on the growth of $E$. coli and Salmonella typhimurium (Helander et al., 1998). The results of our study demonstrated that diets containing $100 \mathrm{mg} \mathrm{kg}^{-1}$ and $200 \mathrm{mg} \mathrm{kg}^{-1}$ oregano EO suppressed the $E$. coli, coliform and lactic acid bacteria in the intestine of the Black Sea salmon. Similar to results of 100 $\mathrm{mg} \mathrm{kg}^{-1}$ and $200 \mathrm{mg} \mathrm{kg}^{-1}$ oregano EO diets, Al-Sagheer et al. (2017) found that feeding Nile tilapia with lemongrass (Cymbopogon citratus) or geranium (Pelargonium graveolens) essential oil containing diets at levels of
$400 \mathrm{mg} \mathrm{kg}^{-1}$ significantly decreased the number of coliforms and $E$. coli. The suppressive effect of oregano EO on the intestinal microbiota (E. coli, coliform and lactic acid bacteria) may be due to its antimicrobial properties. According to Espirito Santo et al. (2018) and Abdel-Latif et al. (2020 a), oregano EO has antibacterial activity. Similarly, Alagawany et al. (2020) stated that thymol has an antimicrobial effect against pathogen bacteria. Besides, similar to our results obtained with the diet containing $50 \mathrm{mg} \mathrm{kg}^{-1}$ oregano oil, Giannenas et al. (2012) found that feeding diets containing carvacrol or thymol did not affect the coliform and E. coli in the rainbow trout.

\section{Conclusions}

It can be said that the dietary supplementation of 50 $\mathrm{mg} \mathrm{kg}{ }^{-1}$ oregano EO showed a tendency to increase the survival and growth performance of Black Sea salmon juvenile. In addition, dietary supplemented oregano EO showed antimicrobial properties by decreasing the count of intestinal bacteria compared to control group. Moreover, a diet containing 50 and $400 \mathrm{mg} \mathrm{kg}^{-1}$ oregano EO may have the potential to increase the surface area required for digestion by increasing intestinal villi length. Fish fed with $100 \mathrm{mg} \mathrm{kg}^{-1}$ oregano EO diet showed a tendency to increase the pepsin enzyme activity. In light of these findings, further studies should be conducted by expanding the investigations of the mixture of oregano EO and higher or lower doses of oregano EO to obtain more detailed knowledge about the effect of oregano EO on this fish species.

\section{Acknowledgement}

This research was carried out within the project named "Investigation of possibilities of using some phytobiotic added feeds in feeding of Black Sea trout" supported by General Directorate of Agricultural Research and Policies. TAGEM/HAYSUD/2017/A11/P-01/3.

\section{Data availability statement}

Research data are not shared. All the related data has been given with the article.

\section{Authors' contributions}

Conceptualization, methodology, and design of the experiments, data analysis, validation, manuscript writing, and reviewing: Osman Tolga Özel; Experiments and feeding studies: Osman Tolga Özel and Eyüp Çakmak; Histomorphologic examination: İsa Coşkun; Enzyme analysis: Selin Ertürk-Gürkan; Microbiota detection: Mustafa Türe.

\section{Disclosure statement}

There are no conflicts of interest between authors.

\section{Ethical approval}

This study was conducted in accordance with the guidelines with the approval of the experimental animals 
ethics committee of the Central Fisheries Research Institute (application numberETIK-2017/1).

\section{References}

Abd El-Naby A.S., Al-Sagheer A.A., Negm S.S., Naiel M.A.E. (2019). Dietary combination of chitosan nanoparticle and thymol affects feed utilization, digestive enzymes, antioxidant status, and intestinal morphology of Oreochromis niloticus, Aquaculture, https:// doi.org/10.1016/j.aquaculture.2019.734577.

Abdel-Latif H.M.R., Abdel-Tawwab M, Khafaga AF., Dawood M.A.O. (2020 a). Dietary oregano essential oil improved the growth performance via enhancing the intestinal morphometry and hepato-renal functions of common carp (Cyprinus carpio L.) fingerlings. Aquaculture, 526: 735432.

Abdel-Latif H.M., Abdel-Tawwab M., Khafaga A.F., Dawood M.A. (2020 b). Dietary origanum essential oil improved antioxidative status, immune-related genes, and resistance of common carp (Cyprinus carpio L.) to Aeromonas hydrophila infection. Fish Shellfish Immunol., 104: 1-7.7

Abo-State H.A., El-Monairy M.M., Hammouda Y.A., Elgendy M.Y. (2017). Effect of a phytogenic feed additive on the growth performance and susceptibility of Oreochromis niloticus to Aeromonas hydrophila. J. Fish. Aquat. Sci., 12: 141-148.

Ahmad M.H., El-Gamal R.M., Hazaa M.M., Hassan S.M., El Araby D.A. (2009). The use of Origanium vulgare extract in practical diets as a growth and immunity promoter for Nile tilapia, Oreochromis niloticus (1.) fingerlinges challenged with pathogenic. Egypt. J. Experiim. Biol. (Zoology), 5: 457-463.

Ahmadifar E., Falahatkar B., Akrami R. (2011). Effects of dietary thymol-carvacrol on growth performance, hematological parameters and tissue composition of juvenile rainbow trout, Oncorhynchus mykiss. J. Appl. Ichthyol., 27: 1057-1060.

Ahmadifar E., Yousefi M., Karimi M., Fadaei Raieni R., Dadar M., Yilmaz S., Abdel-Latif H. M. (2020). Benefits of dietary polyphenols and polyphenol-rich additives to aquatic animal health: an overview. Rev. Fish. Sci. Aquacult., 1-34.

Alagawany M., Farag M.R., Salah A.S., Mahmoud M.A. (2020). The role of oregano herb and its derivatives as immunomodulators in fish. Rev. Aquacult., 1-12, doi: 10.1111/raq.12453.

Al-Sagheer A.A., Mahmoud H.K., Reda F.M., Mahgoub S.A., Ayyat M.S. (2017). Supplementation of diets for Oreochromis niloticus with essential oil extracts from lemongrass (Cymbopogon citratus) and geranium (Pelargonium graveolens) and effects on growth, intestinal microbiota, antioxidant and immune activities. Aquacult. Nutr., 24: 1006-1014.

Amer S.A., Metwally A.E., Ahmed S.A.A. (2018). The influence of dietary supplementation of cinnamaldehyde and thymol on the growth performance, immunity and antioxidant status of monosex Nile tilapia fingerlings (Oreochromis niloticus). Egypt. J. Aquat. Res., 44: 251-256.

Amhamed I.D., Mohamed G.A., Almabrok A.A., Altief T.A.S., Bilen S. (2018). Efficacy of dietary Chenopodium album extract on some health parameters, digestive enzymes and growth performance in juvenile Cyprinus carpio. Alint. J. Agricult. Sci., 33: $165-176$.

Association of Official Analytical Chemists. (1990). Official Methods of Analysis of the Association of Official Analytical Chemists, Vol. I (15th ed.). AOAC, Arlington, VA.

Bieth J., Metais P. (1968). The simultaneous presence of trypsin and trypsin inhibitors in some pathological effusions. Clin. Chim. Acta, 22: 639-642.

Bradford M.M. (1976). A rapid and sensitive method for the quantitation of microgram quantities of protein utilizing the principle of protein-dye binding. Analyt. Biochem., 72: 248-254.

Cararo L.M., Sado R.Y., Muelbert B., Borba M.R. (2017). Evaluation of oregano essential oil as a growth promoter and resistance stimulator against Ichthyophthirius multifiliis (Protozoa, Ciliophora) in silver catfish juveniles, Rhamdia sp. (Siluriformes, Heptapteridae). Ciências Agrárias, Londrina, 38: 3871-3886.
Carneiro C.L.S., Assis C.E., Modesto A.L.S., Maciel J.F.R., Campelo D.A.V., Luz R.K., Jener Zuanon A.S., Salaro A.L. (2021). Oregano essential oil (Origanum vulgare) dietary supplementation improved growth performance, body protein retention and muscle hyperplasia of the Neotropical catfish Lophiosilurus alexandri. Aquacult. Nutr., https://doi.org/10.1111/anu.13263.

Dawood M.A., El Basuini M.F., Zaineldin A.I., Yilmaz S., Hasan M., Ahmadifar E., El Asely A.M., Abdel-Latif H.M.R., Alagawany M., Abu-Elala N.M., Van Doan H., Sewilam H. (2021). Antiparasitic and antibacterial functionality of essential oils: an alternative approach for sustainable aquaculture. Pathogens, 10: 185 .

Dinardo F.R., Maggiolino A., Casalino E., Deflorio M., Centoducati G. (2021). A Multi-Biomarker approach in European sea bass exposed to dynamic temperature changes under dietary supplementation with origanum vulgare essential oil. Animals, 11: 982.

Espirito Santo A.H., Brito T.S., Brandao L.L., Tavares G.C., Leibowitz M.P., Prado, S.A., Ferraz V.P., Hoyos D.C.M., Turra E.A., Teixeira E.A., Figueiredo H.C.P., Leal C.A.G., Ribeiro B.A.P. (2018). Dietary supplementation of dry oregano leaves increases the innate immunity and resistance of Nile tilapia against Streptococcus agalactiae infection. J. World Aquacult. Soc., 51: 418-436.

European Commission (2010). Directive 2010/63/EU of the European Parliament and of the Council of 22 September 2010 on the protection of animals used for scientific purposes. The Official Journal of the European Union, 276: 1-79.

Ferreira P.M.F., Caldas D.W., Salaro A.L., Sartori S.S.R., Oliveira J.M., Cardoso A.J.S., Zuanon J.A.S. (2016). Intestinal and liver morphometry of the yellow tail tetra (Astyanax altiparanae) fed with oregano oil. Ann. Braz. Acad. Sci., 88: 911-922.

Giannenas I., Triantafillou E., Stavrakakis S., Margaroni M., Mavridis S., Steiner T., Karagouni E. (2012). Assessment of dietary supplementation with carvacrol or thymol containing feed additives on performance, intestinal microbiota and antioxidant status of rainbow trout (Oncorhynchus mykiss). Aquaculture, 350-353: 26-32.

Gioda C.R., Pretto A., Freitas C.S., Leitemperger J., Loro V.L., Lazzari R., Lissner L.A., Baldisserotto B., Salbego J. (2017). Different feeding habits influence the activity of digestive enzymes in freshwater fish. Ciência Rural, Santa Maria, 47: 03.

Hani Y.M.İ., Marchand A., Turies C., Kerambrun E., Palluel O., BadoNilles A., Beaudouin R., Porcher J.M., Geffard A., Dedourge-Geffard O. (2018). Digestive enzymes and gut morphometric parameters of threespine stickleback (Gasterosteus aculeatus): Influence of body size and temperature. PLoS ONE, 13: e0194932.

Harrigan W.F., McCance M.E. (1976). Laboratory methods in food and dairy microbiology. London, UK, Academic Press Inc.

Heidarieh M., Mirvaghefi A.R., Sepahi A., Sheikhzadeh N., Shahbazfar A.A., Akbari M. (2013). Effects of dietary Aloe vera on growth performance, skin and gastrointestine morphology in rainbow trout (Oncorhynchus mykiss). Turk. J. Fish. Aquat. Sci., 13: $367-373$.

Helander I.M., Alakomi H.L., Latva-Kala K., Mattila--Sandholm T., Pol I., Smid E.J., Gorris L.G.M., Wright A. (1998). Characterization of the action of selected essential oil components on gram-negative bacteria. J. Agricult. Food Chem., 46: 3590-3595.

Heluy G.M., Ramos L.R.V., Pedrosa V.F., Sarturi C., Figueiredo P.G.P., Vidal L.G.P., França I.F., Pereira M.M. (2020). Oregano (Origanum vulgare) essential oil as an additive in diets for Nile tilapia (Oreochromis niloticus) fingerlings reared in salinized water. Aquacult. Res., doi: 10.1111/are.14658.

Infante J.Z., Cahu C.L. (1994). Influence of diet on pepsin and some pancreatic enzymes in sea bass (Dicentrarchus labrax) larvae. Comp. Biochem. Physiol. Part A: Physiology, 109: 209-212.

Kilkenny C., Browne W.J., Cuthill I.C., Emerson M., Altman D.G. (2010). Improving bioscience research reporting: The ARRIVE guidelines for reporting animal research. PLoS Biology, 8: e1000412.

Khafaga A.F., Naiel M.A., Dawood M.A., Abdel-Latif H.M. (2020). Dietary Origanum vulgare essential oil attenuates cypermethrin- 
induced biochemical changes, oxidative stress, histopathological alterations, apoptosis, and reduces DNA damage in common carp (Cyprinus carpio). Aquat. Toxicol., 228: 105624.

Khojasteh S.M.B. (2012). The morphology of the post-gastric alimentary canal in teleost fishes: a brief review. Int. J. Aquat. Sci., 3: 2.

Magouz F.I., Mahmoud S.A., El-Morsy R.A.A., Paray B.A., Soliman A.A., Zaineldin A.I., Dawood M.A.O. (2021). Dietary menthol essential oil enhanced the growth performance, digestive enzyme activity, immune-related genes, and resistance against acute ammonia exposure in Nile tilapia (Oreochromis niloticus). Aquaculture, 530: 735944.

Mohammadi G., Rafiee G., El Basuini M.F., Doan H.V., Ahmed H.A., Dawood M.A.O., Abdel-Latif H.M.R. (2020). Oregano (Origanum vulgare), St John's-wort (Hypericum perforatum), and lemon balm (Melissa officinalis) extracts improved the growth rate, antioxidative, and immunological responses in Nile tilapia (Oreochromis niloticus) infected with Aeromonas hydrophila. Aquacult. Rep., 18: 100445.

Mohapatra S., Chakraborty T., Prusty A.K., Das P., Paniprasad K., Mohanta K.N. (2012). Use of different microbial probiotics in the diet of rohu, Labeo rohita fingerlings: effects on growth, nutrient digestibility and retention, digestive enzyme activities and intestinal microflora. Aquacult. Nutr., 18: 1-11.

Munglue P. (2016). Effects of lotus (Nelumbo nucifera Gaertn.) stamen extract on growth performance, feed utilization and intestinal morphology of catfish (Clarias gariepinus) (in Italic). KKU Res. J., 22 .

Munglue P., Rattana K., Sangchanjiradet S., Jankam A., Dasri H. (2019). Growth performance and intestinal morphology of hybrid catfish (Clarias macrocephalus $\times$ Clarias gariepinus) fed diet supplemented with rice paddy herb (Limnophila aromatica) extract. Asia-Pacific J. Sci. Technol., 24: 1-12.

Navarrete P., Toledo I., Mardones P., Opazo R., Espejo R., Romero J. (2010). Effect of Thymus vulgaris essential oil on intestinal bacterial microbiota of rainbow trout, Oncorhynchus mykiss (Walbaum) and bacterial isolates. Aquacult. Res., 41: 667-678.

Oswald R.L. (1978). Injection anesthesia for experimental studies in fish. Comp. Biochem. Physiol. C: Comp. Pharmacol., 60: 19-26.

Özel O.T., Cakmak E., Coskun I., Çankırılıgil E.C. (2018). Evaluation of growth performance and intestine villi morphology of black sea trout (Salmo labrax Pallas, 1814) fed with different protein levels containing diets. Ege J. Fish. Aquat. Sci., 35: 125-130.

Rafieepour A., Hajirezaee S., Rahimi R. (2019). Dietary oregano extract (Origanum vulgare L.) enhances the antioxidant defence in rainbow trout, Oncorhynchus mykiss against toxicity induced by organophosphorus pesticide, diazinon. Toxin Rev., doi: 10.1080/15569543.2018.1550092.

Ran C., Hu J., Liu W. (2016). Thymol and carvacrol affect hybrid tilapia through the combination of direct stimulation and an intestinal microbiota-mediated effect: Insights from a germ-free zebrafish Model. J. Nutr., 146: 1132-1140.

Ringø E., Gatesoupe F. (1998). Lactic acid bacteria in fish: A review. Aquaculture, 160: 177-203.

Roofchaee A., Irani M., Ebrahimzadeh M.A., Akbari M.R. (2011).
Effect of dietary oregano (Origanum vulgare L.) essential oil on growth performance, cecal microflora and serum antioxidant activity of broiler chickens. Afr. J. Biotechnol., 10: 6177-6183.

Seden M.E.A., Abbass F.E., Ahmad M.H. (2009). Effect of Origanum vulgare as a feed additive on growth performance, feed utilization and whole body composition of Nile tilapia (Oreochromis niloticus) fingerlings challenged with pathogenic Aeromonas hydrophila. J. Agric. Sci. Mansoura Univ., 34: 1683-1695.

Shabana M.S., Karthika M., Ramasubramanian V. (2019). Effect of dietary Citrus sinensis peel extract on growth performance, digestive enzyme activity, muscle biochemical composition, and metabolic enzyme status of the freshwater fish, Catla catla. J. Basic Appl. Zool., 80: 1-9.

Tabak I., Aksungur M., Zengin M., Yilmaz C., Aksungur N., Alkan A., Zengin B., Misır D.S. (2002). Karadeniz alabaliğı (Salmo trutta labrax, Pallas 1811)'nın biyoteknolojik özelliklerinin tespiti ve kültüre alınabilirliğinin araştırılması projesi, TAGEM/HAYSUD/98/12/01/2007 (in Turkish).

Tan C., Wei H., Sun H., Ao J., Long G., Jiang S., Peng J. (2015). Effects of dietary supplementation of oregano essential oil to sows on oxidative stress status, lactation feed intake of sows, and piglet performance. Hindawi Publishing Corporation BioMed Research International, Article ID: 525218, 9 pp.

Tseng H.C., Grendell J.H., Rothman S.S. (1982). Food, duodenal extracts, and enzyme secretion by the pancreas. Am. J. Physiol. Gastroint. Liver Physiol., 243: G304-G312.

Ture M., Altinok I., Alp H. (2018). Effects of cage farming on antimicrobial and heavy metal resistance of Escherichia coli, Enterococcus faecium, and Lactococcus garvieae. Microb. Drug Resist., 24: 1422-1430.

Valladao G.M.R., Gallani S.U., Kotzent S., Assane I.M., Pilarski F. (2019). Effects of dietary thyme essential oil on hemato-immunological indices, intestinal morphology, and microbiota of Nile tilapia. Aquacult. Int., https://doi.org/10.1007/s10499-018-0332-5

Versaw K.W., Cuppet L.S., Winters D.D., Williams L.E. (1989). An improved colorimetric assay for bacterial lipase in nonfat dry milk. J. Food Sci., 54: 1557-1558.

Worthington T.M. (1982). Pepsin enzymes and related biochemical, Freehold N.J. Worthington Diagnostic System Inc. Retrieved from http://www.worthington-biochem.com/index/manual.html.

Zhang R., Wang X.W., Liu L.L., Cao Y.C., Zhu H. (2019). Dietary oregano essential oil improved the immune response, activity of digestive enzymes, and intestinal microbiota of the koi carp, Cyprinus carpio. Aquaculture, https://doi.org/10.1016/j.aquaculture.2019.734781.

Zheng Z.L., Tan J.Y.W., Liu H.Y. (2009). Evaluation of oregano essential oil (Origanum heracleoticum L.) on growth, antioxidant effect and resistance against Aeromonas hydrophila in channel catfish (Ictalurus punctatus). Aquaculture, doi: 10.1016/j.aquaculture.2009.04.025.

Received: 7 V 2021

Accepted: 26 VIII 2021 